
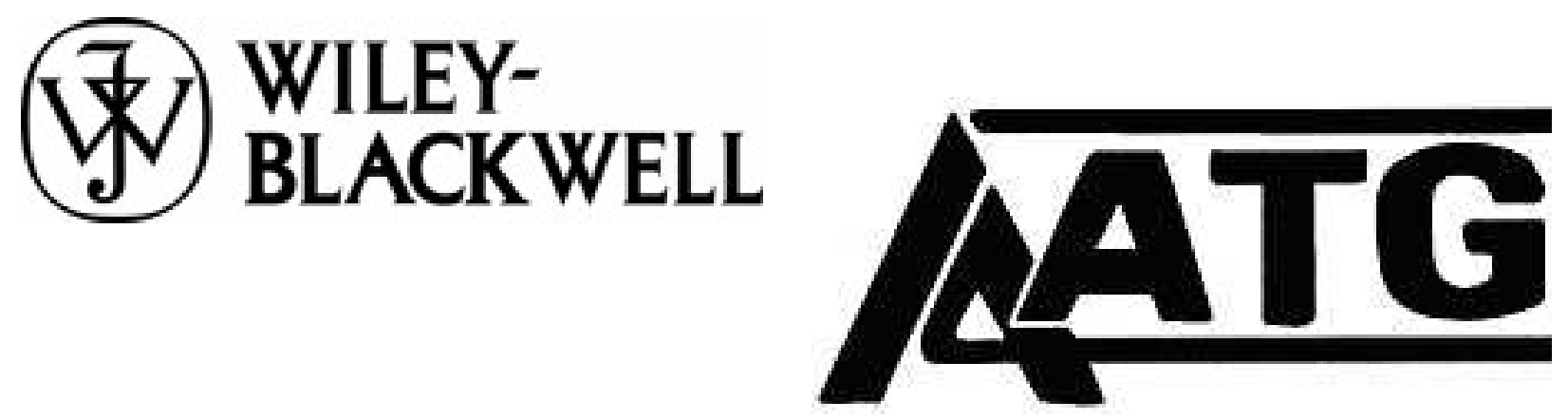

The Rhetoric of Originality: Paul Celan and the Disentanglement of Illness and Creativity Author(s): Derek Hillard

Source: The German Quarterly, Vol. 75, No. 4 (Autumn, 2002), pp. 394-407

Published by: Blackwell Publishing on behalf of the American Association of Teachers of German

Stable URL: http://www.jstor.org/stable/3252210

Accessed: 05/10/2011 12:05

Your use of the JSTOR archive indicates your acceptance of the Terms \& Conditions of Use, available at http://www.jstor.org/page/info/about/policies/terms.jsp

JSTOR is a not-for-profit service that helps scholars, researchers, and students discover, use, and build upon a wide range of content in a trusted digital archive. We use information technology and tools to increase productivity and facilitate new forms of scholarship. For more information about JSTOR, please contact support@jstor.org. 
DEREK HILLARD

Kansas State University

\section{The Rhetoric of Originality: Paul Celan and the Disentanglement of Illness and Creativity}

The mythical link between creativity and illness is like a cat with multiple lives: in the $18^{\text {th }}$ century, as some German writers first codified it in a modern framework others attacked it. Yet even ideological struggles against this link have often had the effect of rejuvenating its mythical force. Both the writings of genius and madness have traditionally appeared as articulations of a basically original and irreproducible nature. In this sense, the concept of origin is key to the cult of the irrational genius. Indeed, origin and originality power not only the discrete discourses of madness and writing, irrationality and creativity, but also their very coupling. Art, it seems, relies on the irrational aura that origins lend it. Yet what happens if aesthetic production does not root itself in the determined unreason of creative origins, but in imitation, semblance, and repetition?

In its $18^{\text {th-century form, the link between }}$ madness and creativity responds to French Enlightenment arguments that classical, rationally comprehensible models are the true originals that must be emulated. In the logic of rhetoric, origins serve to legitimize the positions that speakers take. Western Europe had long justified particular, historically determined forms of politics, society, and art by elevating them to superhistorical models with privileged origins. Monarchs ruled because they descended from heroic precursors; society took a hierarchical organization because it traced itself back to divine patterns; aesthetic norms prevailed because they derived from classical models. Yet as $18^{\text {th }}$-century writers like Herder noticed, the use of origins for legitimacy becomes absurd when a plurality of aesthetic, social, and political phenomena exists, each with its own origin. ${ }^{1}$

This plurality of origins caused writers to confront extensive implications that ultimately generated the figure of the irrational genius as an explanation for origins. Yet, the most significant factor in this shift is something very different from a plurality of origins: at stake was the very event of originality itself. Within their proper discursive fields, aesthetic and sociopolitical models now had to posit their own origins. Poetic and poetological texts took on the role of positing origins. Herder, comparing the original, authentic poet with divinity, makes this clear. For him, the artist who eavesdrops (belauschen) on nature and produces from it art is "der eigentliche Mensch, und da er selten erscheint, ein Gott unter den Menschen. Er spricht und tausende lallen ihm nach." ${ }^{2} \mathrm{Her}$ der contends that the genius, with his initially incomprehensible works, explains how culture generates products that cannot be deduced from models.

A detailed consideration of the way this curious historical shift came about would be an interesting undertaking but would exceed the scope of this study. What interests me here is the way the connection of genius, madness, and origin is again at stake in the wake of $20^{\text {th }}$-century totalitarian politics. I locate the reexamination of this connection in two poems by Paul Celan- "Tübingen, Jänner" (1961) and "Ich trink Wein" (1969). These poems invite and address the question of what happens when aesthetic production is not rooted in the unreason of creative ori- 
gins, but rather in imitation, semblance, and repetition?

My discussion places these poems in the context of the discursive history of madness and genius, and investigates Celan's critique of this culturally constructed link. Particular attention will be paid to the poetic technique of repetition and semblance, and to Celan's recitation of Hölderlin. These poems seek to undermine the notion of prophecy and origins at the center of the genius ideology. In them, Celan returns to the coupling of illness with writing not only to disentangle them but also to redeem madness by removing it from a psychological discourse. Thus, for Celan, writing provides neither access to origins nor one-to-one correspondences to external, non-linguistic things, rather it produces illusions and words that will be repeated and altered. In his poetry, this repetitive nature of writing is figured as a kind of Wahn. The disentanglement of madness and poetry, the critique of original geniality, and the reinterpretation of madness itself emerge as politically and ethically motivated.

The history of the genius has been narrated. ${ }^{3}$ However, readers have overlooked the way the connection between the discursive field of madness and the concept of originality culminates in the $18^{\text {th }}$-century figure of the genius. Johann Georg Hamann was the first to assert fiercely the link between madness and the genius in Germany's $18^{\text {th }}$ century intellectual scene. ${ }^{4}$ Arguing that prophets, notable writers, and poets bore "die Wirkung eines Genies" (104), he claimed that a divinely inspired form of prophetic enthusiasm could manifest itself as madness and that these poets and prophets were denounced because they were seen as being mentally ill. Hamann's views reveal the dual value of madness as both affliction and badge of distinction: depending on the observer's position, the same phenomena count as madness in terms of either an enthusiastic and prophetic higher truth or a purely negative, abnormal condition.

This connection between creativity and divinely fated, poetic madness continues in various forms well into the $20^{\text {th }}$ century. PreRomantic and Romantic culture was enamored with the myth of the genius's madness as a form of divine intervention. This discourse bestowed upon the creative figure the quality of madness whereby he derived his singularity. Madness was, on the one hand, an enthusiasm, or on the other hand, divine retribution for having dared to transgress human limitations. Either way, the mad poet's link to god is the channel for the world's enchantment with a divine presence.

To be sure, late $18^{\text {th }}$-century culture had witnessed the separation of religion and art, the differentiation into distinct social spheres described by Max Weber. Hamann was perhaps the last key player in the intellectual scene who held onto the notion of direct, divine inspiration. Yet, in compensating for the gap left by this move away from explicitly divine connections, writers turned to vague claims of divinely natural powers as a form of genial inspiration. Hölderlin's first biographer, Wilhelm Waiblinger, codified a view of Hölderlin that his poetry would invite: "Einer der wahnsinnig wird aus Gottestrunkenheit, aus Liebe und aus Streben nach Göttlichem."

Michel Foucault provides ample evidence that society long viewed the mentally ill as flawed, antisocial figures. ${ }^{6}$ Add to this the $18^{\text {th-}}$-century notion that the genius is "autistic," and one begins to see the barely concealed similarity between genius and madman. Both are seemingly self-absorbed, act independently, and define their reality without reference to exterior authorities. Autonomous, they appear to speak to and address either themselves or no one. This autonomy, however, reveals a paradox and a price to pay. The creative individual can only posit itself by liberating itself from societal constraints, prevailing ideologies, and frustrating aesthetic norms. Yet madness describes the genius's fate; for the very act by which he asserts himself also makes him ill. In works by Goethe (Tasso), E. T. A. Hoffmann (Die Elixiere des Teufels), and Büchner (Lenz), the writer pays for his sensitivity to the con- 
tradiction between art and life with his sanity. As a result of the break between the real and the imaginative the genius drifts from reality into a Wahnwelt that discursively compensates as salvation for an absent, blessed state.

That madness occupies a shared ground with originality is at first not evident: both the products of genius and madness may seem to be fancy; they neither ground themselves on a universally accessible logic nor define themselves based on previous models. A form of originality, though standing in contradistinction to the form proper to poetry, madness is a seemingly empty and perverted form. This is because the essential function of the genius in his modern incarnation locates itself in the concept of originality, what Kant in the Kritik der Urteilskraft calls the genius's "erste Eigenschaft." The genius defines and makes possible a precious, divinely natural resource, renewable only through him who can access the source. Kant acknowledges the affinity between madness and geniality and that both are joined by the principle of originality. Yet the fact that other works will follow and model themselves after a genial predecessor - through this repetition actually producing the original as original-would distinguish poetry (genius) from madness. In other words, the poet would produce works that will later provide the rules by which future works of art can be created and judged. The product of madness, on the other hand, is a freak occurrence, a negative originality that never becomes a rule.

Science provides $19^{\text {th }}$-century culture with the dominant episteme and metalanguage for explaining itself. Examining the role of scientific explanations for the world, Weber argued that Western society is the society of "Entzauberung." Rational, intellectual explanations for both nature and society visibly replace the meanings of the world that rest primarily on magical, stereotypical interpretations. For Weber, this intellectualism is the claim that all natural and cultural phenomena can be clarified, that one could prove that no irrational powers were at work, "daß man vielmehr alle Dinge-im Prinzip -durch Berechnen beherrschen könne." It can be no surprise then that the logic of science comes to define the link between creativity and madness; science promises the end of the divine ground for this link. Yet in a peculiar twist, the promise is not kept; for the very scientific language that assists in separating religion from the aestheticrather than presiding over the dissolution of the discursive field of madness and creativity altogether-reintroduces into this field the atmosphere of prophecy and myth. It accomplishes this through scientific rhetoric of pathological decline.

Goethe's Tasso and Schopenhauer's genius, wedded to the search for the ideal, already contain the seeds for the mid $19^{\text {th }}$-century reinterpretation of creativity in terms of decline. For many $19^{\text {th }}$ and $20^{\text {th }}$-century writers, this separation from life's vitality, revealed the creative personality's essential intellectual decadence. Cesare Lombroso first popularized the theory of the decadent genius in his Genio e follia (1864). Later, Max Nordau, in his monograph, Entartung (1892), codified the notion of entartete Kunst, pressing the genius into the turn-of-thecentury grand narrative of irredeemable cultural decline. The National Socialists coupled what they termed "entartete Kunst," the product of psychologically degenerate humans, with the Jews, who functioned in fascist ideology as the modern, culturally and mentally ill source of an ethnically debased artistic production. This claim ran concurrent with assertions by many leading scientists from Jean Martin Charcot to Emil Kraepelin and Richard von Krafft-Ebing that Jews, due to generations of inbreeding, revealed a much stronger tendency toward mental illness than other racial groups.

Celan was well informed about the association that writers made between psychological decline and poetry. In 1946, the year before Celan's first German poems appeared in print, Alfred Margul-Sperber-Celan's later key literary supporter and the most influential of the pre-WW II writers of Ger- 
man-speaking Romania-published, in a Czernowitz German-language literary journal, a follow-up article to a scandal that had broken out some years earlier. Celan's birthplace, Czernowitz, had at one time become the center of attention in the debate that powered the discursive link between insanity and the aesthetic. Sperber and a physician posted at an insane asylum published a poem in a newspaper purportedly written by a mental patient. The article sparked an impassioned response by Karl Kraus. ${ }^{9}$ For some, the madness of writers was the sign of creativity in decline. For Kraus, however, "Irrsinn" preserved-through its biological association with the nervous system and inner compulsions thought to cause insanitythe spontaneity that art in an age of intellectuals had all but lost (221-22).

Celan's interest in the problem of reason and unreason had old roots. It is evident in his first published poems of 1947. In an early poem, "Die letzte Fahne," "Wahn" is the very appearance of illusion, and the dilemma constituent to appearances - that one cannot be sure whether they are real or delusionary. ${ }^{10}$ By the early 1960 s, after establishing himself in Paris, Celan had encountered new discourses that discussed madness as a problem not only of psychology and philosophy individually, but also in terms of their agonistic relationship (Maurice Blanchot, Foucault, and Jacques Derrida, and from the Germanspeaking world, Ludwig Binswanger). Not only did the question of Wahn play a role in Celan's translations of the poets whose work interested him-Mandelstam, Jessenin, Nerval, and Artaud-but also in his encounters with the fragile figure of Lenz in the Büchner speech and "Gespräch im Gebirg."

My position is that Celan, in reexamining the topos of the mad poet in "Tübingen, Jänner" and "Ich trink Wein," critiques the link between illness and writing/creativity and disentangles this connection. For Celan, the correlation of madness to writing is a cultural construction that, according to the logic of this discursive link, enchants writing with a divine aura of prophetic force, or in- versely, turns writing into a mechanical product of uncontrollable biological urges. To disentangle madness from writing, Celan does not go directly to the late $19^{\text {th }}$-century image of the decadent artist that biological sciences explained. Rather by returning both to the image of Hölderlin as the quintessential mad poet and to the $18^{\text {th }}$-century connection of a divine, poetic enthusiasm, Celan skirts a scientific explication and reinterprets madness as precisely the opposite of originality: madness is language's constituent feature of imitation. For Celan, poets cannot create ex nihilo. They work with the history that marks language and a language marked by historicity. Instead of an Adamic writing, which corresponds word to thing, for Celan words can only be reinscriptions of other words. This means that a curious wealth of signification and communication is in force. For as Celan asserts in his "Meridian"-speech, one poem, through quoting another text, cannot reproduce the full situation of that previous text. Instead, by means of this rewriting, it participates in the production of yet another situation and the erasure of a previous one. According to Celan's two Hölderlin poems - their complex interrelationship of theme and form-writing is always already set free from origins; for the very fact that words can be written means that they are repeatable and not bound to a determined and determining origin. Finally, for these two poems, madness defines the condition of signification in modernity. It is language's proliferation and the incommensurability of language games.

Tübingen, Jänner

Zur Blindheit über-

redete Augen.

Ihre - "ein

Rätsel ist Rein-

entsprungenes" - , ihre

Erinnerung an

schwimmende Hölderlintürme, möwenumschwirrt.

Besuche ertrunkener Schreiner bei diesen 
tauchenden Worten:

Käme,
käme ein Mensch,
käme ein Mensch zur Welt, heute, mit
dem Lichtbart der
Patriarchen: er dürfte,
spräch er von dieser
Zeit, er
dürfte
nur lallen und lallen,
immer-, immer-
Zuzu.

("Pallaksch. Pallaksch," GW I, 226)

The title is the poem's opening salvo against an ideology of origins and an implicit theory of language anchoring readability in original contexts that seemingly saturate meaning. It alone evokes the myth of Hölderlin and its successive regenerations (from early visitors such as Brentano to the writings of George and Heidegger). The myth of the blinded, mad genius had begun; it prevailed until Celan's "Tübingen, Jänner" and Adorno's "Parataxis"-speech for the Hölderlin-Gesellschaft in Berlin the same year (1961). ${ }^{11}$ Readers maintain that by placing "Tübingen" and "Jänner" together, the poem either evokes a past moment that is no longer accessible to cognition, or that it combines this particular city with a multiplicity of other places and times. ${ }^{12}$ Yet the poem does not combine the time and place of Hölderlin with a limited set of others, but uproots this myth. Jänner takes on specific roles in Celan's poetry in light of his Büchner-speech in which the 20. Jänner becomes a cipher for the law of the date itself, memory, madness, totalitarian politics, and biography. ${ }^{13}$ The title ("Tübingen, Jänner") recites the month with its regional orthography. Yet because it stands alone without a specific date beyond the month, it asserts an independence from the Jänner and the meanings with which Celan inscribes it in the Büchner-speech. In this poem, Jänner neither specifically recites the Wannsee Konferenz's date of January 20, 1942-as Celan's speech "Der Meridian" does -nor evokes Büchner's Lenz, from which
Celan drew the date (even though the poem's penultimate two lines quote Büchner). Instead, this title and first line of the poem, the reinscription of Tübingen and Jänner as a temporal marker itself, dislodges the time, place, and situation of Hölderlin. It remains true to the function of the date in Celan's poetry: its repetition clashes with a previous situation, day, and text, and marks this past situation's erasure. Memory is a form of wiping out.

The way Celan's poem frames numerous, indeterminate, literary recitations and intertextual connections undermines a notion of art as the product of original, mad origins. Beyond the title's possible source in Büchner's Lenz, it not only recites a passage from Hölderlin's poem "Der Rhein," but also highlights the passage as a recitation through the quotation marks. The final line furthermore quotes a word Hölderlin was said to utter during his insanity, "Pallaksch," which could mean either Ja or Nein. Readers of Hölderlin have uncovered other, more tenuous intertexts. ${ }^{14}$ Near the poem's end, it quotes from Büchner's play Woyzeck:

immer-, immer-

zuzu

At the core of the ideology of origins lies a claim of authority, and Celan's quotation of Hölderlin critiques this core. The first line of strophe IV from Hölderlin's poem, from which Celan quotes, defines the inspired poet's capability: "Ein Rätsel ist Reinentsprungenes." ${ }^{15}$ In Hölderlin's text, the poet, embodied in the river as a figure for consciousness, emerges essentially fully formed and fated ("Wie du anfingst, wirst du bleiben"). While culture and history ("Zucht" and "Not") are important, an original, vital, natural force ("die Geburt" and "der Lichtstrahl"), which produces and guides the poet's consciousness, is the most decisive. As in the first strophe of Hölderlin's poem "Der Rhein," where the poetic Ich sits, "[d]en Quell besuchend," the divine aspect of nature continuously leads the poet to the source. ${ }^{16}$ Celan's recitation exactly contra- 
dicts the line's claim of original, divine donation.

Celan's fragmentation of Hölderlin's prophetic statement disperses what was a single, gnomic line over three lines of his own poem:

$$
\begin{aligned}
& \text { Ihre - "ein } \\
& \text { Rätsel ist Rein- } \\
& \text { entsprungenes" -, ihre }
\end{aligned}
$$

The typographical change from the "Ein" to "ein" chops the beginning of Hölderlin's sentence and embeds what was a mystical origin in Hölderlin in the body of Celan's poem as context (Zbikowski 194). In Hölderlin's "Der Rhein" the stress falls on Rätsel, in which the statement is general, as if given in an $18^{\text {th }}$-century intellectual intuition. Celan's poem, on the other hand, stresses the ein. This reversal of stress explicitly makes Hölderlin's passage and Celan's rewriting of it into specific determined claims, erasing an aura of the given. The breaking of the verse marks the particularity of Hölderlin's poem, historicizing it, calling attention to Celan's text as a recitation and replacement of a prior situation.

By framing Hölderlin's utterance about and purportedly of singular origins with quotes and dashes, Celan, with his repeated pronouns, "ihre," contradicts in this formal sense the meaning of originality. The recited words, which belong to eyes that have been blinded by too much speaking, define the reinterpretation of madness that Celan aims to accomplish:

Zur Blindheit überredete Augen.

Through breaking the word, über-reden, a different meaning-"too much talk"emerges and erases the meaning of "to convince." The eyes blinded by an excess of speech belong to the Hölderlinian myth of the mad, prophetic poet. Blindness is not only mythically central to prophecy; it is also a synonym for madness (madness as a form of blindness; this blindness in turn reinforcing the image of the blind seer). Yet here, Celan uses the madness of Hölderlin's image to critique the notion that a prophetic writing can name and order the world. Celan thus inscribes the topos of too much language into his poem. The madness of a proliferation of words and languages-a tower of Babel-is the result of an excess of speech. This excess of cultural, symbolic production is the fall from the purity that suggests fated, given origins and an original language inscribed in Hölderlin's poem. In short: that symbolic production, especially speech, is always too much is the madness of modernity. Likewise, for Walter Benjamin, in his essay "Über die Sprache überhaupt und über die Sprache des Menschen," it is precisely this excessive nature of speech, the "Überbenennung" of things that causes mourning and brings about the speechlessness of melancholy in a post-paradisiacal age. ${ }^{17}$

In the turn from blindness to insight that occurs in the topos of the blind seer (a surface blindness pointing to a deeper vision), words easily invert to their opposites. Many readers of "Tübingen, Jänner," following the myth, ascribe a mystical, visionary capability to the blindness of these eyes and fall into the trap of this inversion (Geier 20-21). Böschenstein uses myth critically in his effort to understand myth, going so far as to press Celan into the Hölderlinian image of the blind prophet: "Dieser Blinde [Hölderlin] war aber der Sehendste. So ist jetzt auch der, der ihn aus der Ferne sieht. Beide entsagen dem Licht, weil sie das Licht reiner erkennen." 18 This reading established and continues to support interpretations of the poem that view Celan as the modern day poet who, like Hölderlin, experiences a linguistic and epistemological crisis and must come to terms with writing poetry "in dürftiger Zeit" (Böschenstein 103). In this way critics comfortably reinsert Celan into the myth that his poem effectively undermines.

For Celan, the rewriting of Hölderlin's "reinentsprungenes" is madness. This is the determinant moment of "Tübingen, Jän- 
ner" where the poem goes beyond the effect of decoupling madness from writing. In his replacement of imitation and repetition for originality and inspiration Celan discursively reinterprets madness. It is with an eye to what one contends is a fact of language, its repeatability, that he critiques the ideology of the mad poet. The madness of modernity entails an exposure to the repeatability and proliferation of language, the unavoidable excess of symbolic production, which blinds the eyes in "Tübingen, Jänner." The blindness is not a consequence of having drunken from a source of creativity, as in the myth of the genius. Rather, madness is the constituent feature of writing to become dispersed into different languages and functions and be uprooted from fixed contexts and origins. The eyes' memory-a form of repetition itself-does not recall a singular moment. Rather it names the dispersal of "schwimmende Hölderlintürme." This dispersal evokes the many myths of Hölderlin that are rooted in a prophetic, tragic illness, as well as the readings of these myths, a babble (the "Turm" itself graduating from Hölderlin's tower to that of Babel) of memories and interpretations.

Because it signifies a proliferation of both perspectives and languages, what JeanFrançois Lyotard refers to as the concept of "languages games," "which accepts agonistics as a founding principle," Wahn, is ethically motivated. ${ }^{9} \mathrm{Nazi}$ politics subsumed all languages and social spheres beneath the one metadiscourse of racial destiny. A poetry of Wahn, a tower of Babel, not only describes and practices a writing of agonistic languages as a historical condition, it also has the effect of interrupting constructions of total perspectives.

The words Blindheit and Augen, of course, move the poem's language into a discourse of visual perception. Celan's poetry commonly combines vocabulary that connotes vision, on the one hand, with vocabulary that connotes speech, reading, or writing, on the other. In "Tübingen, Jänner" this combination of reden and Augen has a specific effect.
This poem attributes a shared penchant to the mechanics of both perception and speech (writing and reading). Both perception and writing are systems driven by semblance and repetition. Writing is the rewriting of other phrases and not a medium for attaining access to essential or original phenomena. So too is perception an act by which the eye registers "illusions" that provide an imperfect knowledge about visual phenomena, that is, about other illusions. Thus the quality of semblance inherent to writing and perception makes them both wahnhaft, and the knowledge that a world of appearances provides is subject to the uncertainty of illusions.

It is perhaps no surprise that a poem criticizing origins and prophecy turns to a vocabulary of a paradisiacal age. The repetition of the subjunctive wish-in which its construction by accumulation is laid barestands in contrast to the statement's prophetic content:

Käme,

Käme ein Mensch,

Käme ein Mensch zur Welt, heute, mit dem Lichtbart der

Patriarchen:

Celan's Mensch, which remains a subjunctive, hypothetical figure, would bear the "Lichtbart" of the patriarchs. He would come or be born (zur Welt kommen)-Celan combines the figures of the newborn and the genius linked by their attributes of intuition and freedom from unnatural norms-with an originary language. The beard of fire functions metonymically for a speech of fire, in which the Mensch would have the inflamed speech of the originary fathers, the patri-archs. This language of an illuminated, law-giving logos (the "Lichtbart" that echoes and twists Hölderlin's "Lichtstrahl") would preserve congruity between thing and word, between divine origin and symbol. The Mensch of such an imagined moment, one prior to both history itself and any struggles against the authority of the father-patri- 
archs, contrasts with the actual situation of heute, in which life is not conditioned by origins and essences, but by repetition and semblance.

Celan uses the Mensch to argue that words represent other words and situations that are marked by textual contexts-not objects that are totally external to linguistic dimensions, certainly not origins. Should this Mensch appear today and speak of "this" time-the reference of "dieser" contains both the possibility of the $20^{\text {th }}$ century and the time of the patriarchs-it would be permitted only to babble like a child: "nur lallen und lallen." The language of the newborn or the genius as newborn is seemingly original; the genius goes to a mythical source to receive a divine language. Celan's poem then reinterprets Herder's concept of "der eigentliche Mensch," who goes to nature to create divine products of which others can only produce a Nachlallen. All speaking in modernity is a Nachlallen. Unlike that of Herder's, the language of Celan's Mensch appears after the fall; it is Geschwätz, in the sense in which Benjamin uses the term in his essay, "Über die Sprache überhaupt und über die Sprache des Menschen," where a fallen language is one that communicates something other than itself (153). Lallen reflects the proliferation of languages and various linguistic categories of limited historically determined knowledge. This decisive caesura with an imagined paradisiacal past is such that even the prophetic Mensch in "Tübingen, Jänner" would be exposed to the conditions of signification and speech of modernity. From the perspective of an original, given language, his speech would, today, be just another case of chatter. In other words, he could only communicate in historically conditioned, eminently repeatable and incommensurable languages (languages without a metalanguage under which they could be subsumed). The repetition of the word"lallen und lallen"-describes the conditions of an actual, historical speech in which a meaning first emerges with repetition and repeatability. This break with a mythical and original language is the moment of modernity, or in terms of another poem, "Huhediblu," Wahn. The poem's production of semblance (rewritten words) defines the modern as opposed to a time of Adamic speech.

Celan constructs the poem's final four lines around the reversal of Hölderlin's language of a purely original poetry as the source, as well as madness in terms of genial enthusiasm:

nur lallen und lallen, immer-, immer-

zuzu.

("Pallaksch. Pallaksch.")

Against the originality of the genius's law-giving imagination-as in Kant's famous definition of the genius-and the aura of madness in terms of a singular, incomparable utterance, the poem develops a pattern of repetition and recitation. The last four lines consist almost exclusively of repetitions-the most pervasive rhetorical device of Celan's poetry. "Tübingen, Jänner" cites what are almost certainly the lines of Büchner's mentally ill figure, Woyzeck, at the moment of his madness, his Stimmwahn, as he hears voices and makes plans to kill his girlfriend. ${ }^{20}$ The poem's quotation of Woyzeck excludes the psychological scene and connotations of Büchner's drama, transforming this into the madness of repetition. Not only the rhetoric of recitation is at work; the repeated word has the meaning ("immer-, immer-/zuzu") of the event of repetition, which conflicts with the assertion of pure origins in Hölderlin's quoted poem.

The last line-the utterance "Pallaksch" is attributed to Hölderlin by his first biographer, Christoph Theodor Schwab-encapsulates Celan's technique. That Celan was aware of the legend behind this word is beyond dispute; for he writes in a letter to his lover, Ilana Schmueli, in 1969: "darunter soll Hölderlin, in der Zeit seiner Umnachtung, Ja und zugleich Nein verstanden haben."21 On its own, "Pallaksch" is seemingly a pure 
chance word (Breithaupt, 650). Appearing once, it would remain an emphatic evocation of Hölderlin's divine, mad utterance. It would become an enchanted word whose encrypted mystery persists in defiance of a rationalized world. Celan repeats precisely this word that is overcoded with contexts of madness. That which happens once, as the adage goes, is an accident, twice a coincidence, and three times a pattern. Chance is typically understood in singular terms. Yet this is only partially true; the single occurrence may also possess the appearance of what is divinely given. In this sense, the products of the genius are seen as unpredictable, singular and divinely inspired works. The language of madness, on the other hand, appears as a meaningless, chance event (or its only meaning is its singularity). Celan's repetition of Hölderlin's Pallaksch works against both the singularity of the genial product and the nonsense of a random utterance having no conventional meaning. It takes on meaning only with its repetition. Only in this way can it become a word, rather than a chance utterance. Celan's repetition of the word effectively removes Hölderlin's poetry from the field of psychological madness. Chance however is not banished completely from the poem. For though Celan repeats the word, by making meaning - which it would not have as a purely chance event-possible through its repetition, the particularity of its meanings cannot be completely determined.

Readers working against the nearly crushing tide of biography, sentimental anecdote, and positivism in Celan scholarship have forcefully argued that this poem does not convey a biographical moment. Nevertheless, "Tübingen, Jänner" brings together what Derrida provisionally refers to as the poem's "exterior" (the date at which Celan wrote the poem) and "interior" (the dates that the poem encodes) dates..$^{22}$ The title stands in an inexact correlation to the date of the poem's writing and situation. Indeed, $\mathrm{Ce}-$ lan wrote the poem, a variant title of which included "1961," on January 29th, 1961, after returning to Paris from a one-day visit to
Tübingen. Celan was in Tübingen to receive a written position paper from Walter Jens that he believed might help him in his efforts to respond to the charges of plagiarism leveled against him by Claire Goll, the widow of the poet Ivan Goll. That Celan begins "Tübingen, Jänner" with a marked quotation of Hölderlin's "Der Rhein," which thematizes originality, is significant in light of the purpose of this visit. The poem undermines the cult of innovation, its theoretical implications and underpinnings in terms of authoritative, authorial guardianship of meaning. Claire Goll used precisely the seemingly innocuous concepts of originality and authorial propriety to attack Celan's poetic production by accusing him of plagiarizing her husband's works. “Tübingen, Jänner" calls into question the author's proprietary claim to texts. Celan's analysis of origins, however, is not only, not primarily, "personal." Rather, he levels his critique at the politics of originality.

In "Tübingen, Jänner," Celan's recitation of Hölderlin's "Der Rhein" in his division of the crucial word (über-reden) discredits authority derived from origins. Celan explicitly uses specific, repeated words ("lallen," and "Pallaksch") which, if appearing only once, would be "glossolalia" (the incomprehensible words of mad poetry), with the effect of staging a clash with the poem's rhetoric of originality. Thus both through the precise use of quotation marks and repeated key words (including the insane utterances of Woyzeck), Celan posits that all writing is wrenched from determined origins: one cannot attribute statements to vague theological originality. By textually inscribing the name Hölderlin and the topos of mad poetry, Celan appropriates the madness of this tradition. Yet he takes on the qualities of prophetic enthusiasm and psychological abnormality only to reinterpret madness as the constituent aspect of language that humans face. Once we have written words, we set them free and will use them in arbitrary contexts with no necessary relation to real, external objects or origins. By pointing to the 
poem's figure of a blinding excess of speech, I have claimed that, for Celan, madness is the penchant of language to frustrate human attempts to turn it into a reliable instrument. This is because the range of languages produces an incommensurability, and the disjunct between words and origins makes it impossible to see in language a system of seamless correspondences.

While "Tübingen, Jänner" uses repetition to counter the ideology of originality, Celan's later poem, "Ich trink Wein," returns to Hölderlin and madness to undermine messianic notions:

ICH TRINK WEIN aus zwei Gläsern
und zackere an
der Königszäsur
wie Jener
am Pindar,

Gott gibt die Stimmgabel ab als einer der kleinen Gerechten,

aus der Lostrommel fällt unser Deut. (III 108)

"Hölderlin, der immer halbverrückt ist, zackert auch am Pindar." 23 The first strophe of Celan's poem recites this remark made about the "halbverrückt" poet whose translative work on Pindar amounts to a vain effort. Hölderlin was working as the Hofbibliothekar to the Landgraf in Homburg when a civil servant, "Hofrat Gerning," wrote the comment in a letter. Celan found the sentence in Michel's Das Leben Hölderlin, which he read in 1969. Zackern, zacker gen, as Grimms notes, is a medieval word to plow. Etymologically and across numerous languages it is key to philosophy: acre, ackern, agro, agere, to be an agent, to act. The word is also linked to the word for author. In this sense, Celan's plowing away is also an "authoring" on the Königszäsur.

Through comparing the work of the Ich with that of the previous moment ("wie Jener"), this poem erases Hölderlin's pure singularity, his situation's incomparability.
The poem's Ich takes the words written about Hölderlin, where his translations were apparent evidence of madness, and compares them with its own efforts. Celan does this not by quoting from Hölderlin's biography, but by organizing the poem structurally around comparison, which the quotation announces. The Zackern of the Ich is a semblance, "wie Jener," of Hölderlin's Zackern. According to the author of the deprecating comment about Hölderlin, zackern supposedly contained within it the proof of madness. Celan leaves behind the word halbverrückt as well as Hölderlin's name, retaining the action that, for many, proved Hölderlin's poetic insanity. For a moment then the poem is not about madness, but rather about the eradication or omission of a certain kind of madness, that is, a psychological meaning of insanity.

Yet similar to the case of "Tübingen, Jänner," the Wahn both of Hölderlin's action and Celan's poem is present though unnamed in the rhetorical figure of repetition. In Hölderlin's case the incomprehensible and irreproducible character of his Pindar translation attests to his madness as it was for the impending Hölderlin cult to count as his genius. Gerning's remark specifically notes Hölderlin's work on Pindar. In the late $18^{\text {th }}$-century discourse of the inspired, poetic genius and the autonomy of the imaginative subject, Pindar's poetry, the "hohe[ ] Ode nach Pindars Art," counted as the genial "Dichtungsgenre schlechthin nach zeitgenössischer Überzeugung” (Schmidt 172). This reception of the Greek poet is not incidental, as Celan knew; for it is Pindar who first explicitly formulates the idea of an innate poetic ability that cannot be learned. Herder identified Pindar as history's archetypal genius, and the young Goethe wrote odes in which a modern poet wrestles with Pindar's towering image. A barely concealed and only apparent aspect of Hölderlin's late poetry as well as his translations is their originality and incomprehensibility. In contradistinction to originality, the madness of the Ich's Zackern in "Ich trink Wein" consists in the 
repetition and the semblance of the action.

My contention then is that this word wie, for Celan, is the madness of this poem. It is the claim that we may read-and in philosophical terms of appearance-perceive something only as or in comparison with something else. Words do not correspond to given objects in the world; appearances are not grounded in essential entities. Words and appearances are in effect illusions (a meaning of Wahn), though not of hidden, Platonic essences. Rather they are illusions of other illusions. Celan's "Ich trink Wein" is the attempt to represent the very process of representation, by which illusions appear. Words and appearances are only understood in relation to each other and through the differences that pertain between them. Madness names reading and perception in modernity.

This can be illustrated and summarized by returning to the efforts of the poem's Ich. It encodes its own work at comparison as Wahn, just as the incomparability and incomprehensibility of Hölderlin's translations provoke Gerning's comments about Hölderlin's "halbverrückt" translation. Hölderlin's translation seems at first to be the singular and initial moment of "plowing," for which Celan's poem enacts the repetition. Yet this cannot be accurate. The original position of Hölderlin is proven untenable. His Zackern is itself a semblance, a translation of Pindar. Hölderlin too wrote something, wie Pindar, who, in a chain of translating texts, wrote poetry, wie-another.

Since the $18^{\text {th }}$ century, originality and untranslatability have been the key qualities and functions of the irrational poet's inspired productions. Unprecedented creation, the absence and disregard for norms and guidelines, and the autonomy of unbridled subjectivity, are present in both the creative genius and madness. Celan however turns this on its head, making madness into repeatability with a difference. Celan's transformation of Wahn erases the function of accounting for a singular origin for events. Madness, as Celan figures it, empties the cult of the genius of its subjective core. The distinction of the genius historically resides in its capacity to transcend the distance between idea and appearance through the technique of the symbol. ${ }^{24}$ But insofar as, or in those moments when, literature represents, it does not claim to transcend the distinction between the word, on the one side, and essence, reality, and image on the other, that is, between the noumenal world of reason and the phenomenal world of understanding and perception. Rather it concedes that it does the opposite: it provides a chain of non-identical semblances that preserve their distinctions.

Celan employs the compositional technique of similarity and semblance as cornerstones in his case against the claim that appearances and words provide access to secured knowledge.

In the first strophe the Ich is like "Jener"; here god appears "as one of the small just ones." The reduction of god to an appearance of one of many is accomplished in the repetitions of $G$-in this strophe: Gott, gibt, Stimmgabel, Gerechten, denying and emptying out the presence of god's singularity and incomparability.

The image of god surrendering the "Stimmgabel" is a signal that language as a system of utterances that tether themselves to origins and objects is at an end. The "Stimmgabel" is, as Grimms notes, the tool "zur Feststellung und Kontrollierung der absoluten Tonhöhe, von Stimmen" (vol.10, 3117). The word takes on an etymological meaning of stimmen: "etwas nennen, festsetzen," "nahmhaft machen, bezeichnen, anordnen u.s.w. urpsrünglich als eigentliche mündliche Äußerung vorgestellt" (3091). God gives away the "naming-fork," surrendering the means for giving and speaking the names of things, for ordering, arranging, and identifying the phenomenal world. Language, now out of the range of the divine, is disenchanted. What remains are words that we can use to respond to other words and situations - a series of copies and semblances, repetitions without given models. As god turns in the "Stimmgabel," the work in- 
volved in reading, problematizing, and interpreting a speaker's situation, now comes to the fore.

Tipping out of the lottery drum in the final lines is not fate (Los), as one might expect, but the coin, the doit, what has little value, almost nothing:

\section{aus der Lostrommel fältt unser Deut.}

The Deut may evoke Deutung; yet it actually signifies the very potential for meaning. The potential is legible in this complete word for coin that at the same is the fragmented word for Deutung. According to Celan's poem, we receive no fate, no lot. In the place of fate are coins, a circulating medium that we can use to approximate other coins, other words; but these are words for which there is no given standard or value, due to the end of a normative conception of meaning. The Deut that falls from a lottery drum is furthermore the product of chance, a gamble, thus stressing the indeterminacy of moments in which meaning is produced.

Celan's poem mobilizes the trope of humanity's separation from a messiah. The "Königszäsur" is specifically the caesura of the king. ${ }^{25}$ One may link the poem's concern with the king to the two glasses of the first longer line: "ICH TRINK WEIN aus zwei Gläsern." The two glasses connote the chain of texts from Pindar to Hölderlin to the poem's Ich who drinks from them. Zbikowski offers a reading of the two glasses at the beginning of Celan's poem (206). On the Seder evening of the Passover, during which each person receives a glass, a second glass is placed in front of the host's seat, meant for the prophet Elias-a precursor to the messiah. I would briefly extend this reading and argue that in Celan's poem, the Ich drinks from both glasses, emptying out the glass that would otherwise signal a messianic age.

The interruption of the messiah as king interrupts a redemptive narrative. Celan's Zackern on the Königszäsur is a doubled cutting away at a central and meaningful inter- ruption in a redemptive presence. A key letter from the first three lines further accomplishes the cutting: the $z$ in $z$ wei, $z$ ackere, $z$ äsur links these three words whose meaning turns on division. Celan claims that in a world in which the access to the divine or to the ontic reality behind words and images is barred, the power of semblance and comparison remains: writing as recitation without originals, illusion, Wahn. As Celan wrote in a letter: "In der Königszäsur, da stehen wir, liegen wir jetzt" (Schmueli 35). The Königszäsur names a fallen world, and the poem's Ich zackert toward marking and finding a place within this interruption. The attempt itself cannot be a pure success, something that Celan seems to have realized in paraphrasing zackern, to plow and to author with "pfuschen," that is, to bungle (33).

More than "Tübingen, Jänner," "Ich trink Wein" claims that writing and appearances are illusions of illusions, appearances of appearances. For classical theories of knowledge, from Plato to Schopenhauer to the neo-Athenian positions of $20^{\text {th }}$-century thinkers such as Leo Strauss, the world of particular appearances is mere opinion, doxa, delusion, Wahn. This perspective defines appearances to be repetitious counterfeits of authoritative origins or transcendent truths to which we still have access. Materialist claims, on the other hand, consign perception and truth to the realm of material entities only. They deny the reality of imaginative and playful phenomena by which the aesthetic can propose new realities. Celan's poetry offers us a way to think beyond this impasse. Wahn, in this sense, defines the world both in its impoverishment and its wealth. The illusory nature of writing, instead of furnishing us with genuine and primitive meanings, provides imperfect opinions and ways to produce unforeseen actual possibilities that cannot be deduced through strict materialism.

To return to the question that I posed at the beginning-what happens if aesthetic production is rooted not in the unreason of a singular creative origin, but is driven by imitation, semblance, and repetition? Celan's 
answer: a poetry whose task is to mark the illusions that it inscribes as illusions, one viewing itself characterized by a pervasive and textually mediated past. Celan's poems cause a discursive shift in the history of creativity and its relation to madness. Turning away from a redemption from reality in an ideal, aesthetically mediated world, Celan's poetry separates pathology from the aesthetic and brings to an end a mourning of the fractured state of productive, poetic subjectivity. For Celan, the writer no longer runs the risk of going mad in the face of a failed attempt at transcendence or a reconciliation of conflicts. His poetry does not seek to transcend reality or reconcile the vexing oppositions that organize culture: nature and society, real and ideal, immanence and transcendence, representation and experience. Instead, Celan's poetry engenders and explores the reality that he claims to find in words in new situations.

Celan wants us to read the fact of this historicity in all forms of symbolic communication (writing and speaking). The Wahn of poetry for him is its proliferation of repetitions and comparisons, its constituent illusory and imitative capacity. Celan then writes from a position after the battles against the naive conception of mimesis, representation, and the idealist subject that believes itself able to represent a total Weltbild - the critique against representation that Heidegger and the French Heideggerians incisively and obsessively carry out. ${ }^{26}$

Celan's critique of origins and of the very link between illness and poetry is political and ethical. Both models for culturally constructing mad geniality-the Hölderlinian creator who connects the poles of origin and prophecy, on the one hand, and the artist who grows from the negatively tinged soil of ethnic or biological decline, on the othernurtured the political terror of the $20^{\text {th }}$ century in different ways. The first, with its roots in the Herderian notion of the genius/ poet as the mouthpiece of his Volk's local, distinctive spirit, was thought to express both a people's origins and its destined future on a historical stage. Such an ideology established and sustained an image of the specifically German political genius guided by providence, into which Hitler situated himself. The second was used by proto- and fascist ideology to stigmatize Others whom it culturally coded in terms of illness and Jewishness. For Celan, this Jewish writer after Nazi Genocide, separating illness from both literature and ethnicity became a central personal and political concern. His poems of repetition and semblance disentangle writing from prophecy and illness. They erase the aura of authenticity attributed to the cult of the irrational genius.

Yet in a peculiar way, in the very process of Celan's critique, something of this Romantic notion of the revelatory force of madness remains. The Romantic conflict between Dichtung and Wirklichkeit becomes for Celan the possibility of uncovering reality through the writing of poetry (literature as an exploration of what is real). Because, Celan's two poems assert, writing is a form of Wahnas repetition, reorganization, and linguistic incommensurability - Wahn understood in this sense makes possible a pursuit of reality. In this way, Celan retains an abstract privileging of madness and its link to writing. But the $18^{\text {th }}$ - and $19^{\text {th }}$-century writers who codified the mad poet would scarcely recognize this figuration of Wahn. Celan has hollowed out its psychological and prophetic core and disentangled the weave of illness and creativity.

\section{Notes}

${ }^{1}$ See "Shakespeare," Johann Gottfried Herder, Schriften zur Ästhetik und Literatur: 1767-1781, ed. Gunter E. Grimm (Frankfurt a. M.: Deutscher Klassiker Verlag, 1993) 498521.

${ }^{2}$ Herder quoted in Jacob and Wilhelm Grimm, Deutsches Wörterbuch, vol 4 (Leipzig: S. Hirzel, 1922) 3419.

${ }^{3}$ See Jochen Schmidt, Die Geschichte des Genie-Gedankens in der deutschen Literatur, Philosophie und Politik 1750-1945 (Darmstadt: Wissenschaftliche Buchgesellschaft, 1985). 
4Johann Georg Hamann, Sämtliche Werke, Historisch-kritische Ausgabe, vol II, ed. Josef Nadler (Wien: Verlag Herder 1950) 105.

${ }^{5}$ Wilhelm Waiblinger, Friedrich Hölderlins Leben, Dichtung und Wahnsinn (Wurmlingen: Schwäbische Verlaggesellschaft, 1982) 80.

${ }^{6}$ Michel Foucault. Madness and Civilization: A History of Madness in the Age of Reason, trans. Richard Howard (New York: Vintage, 1988).

${ }^{7}$ Immanuel Kant, Kritik der Urteilskraft, Werkausgabe X, ed. Wilhelm Weischedel (Frankfurt a.M.: Suhrkamp, 1994) 242.

${ }^{8}$ Max Weber, Gesammelte Aufsätze zur Wissenschaftslehre, ed. Johannes Winckelmann (Tübingen: Mohr, 1968) 578.

${ }^{9}$ See Ernst Wichner and Herbert Wiesner, eds. In der Sprache der Mörder (Berlin: Literaturhaus, 1993) 221-22.

10Paul Celan, Gesammelte Werke, vol I, eds. Beda Alleman, et al. (Frankfurt a. M.: Suhrkamp, 1983) 23. References appear parenthetically with volume and page numbers.

11Theodor Adorno, Noten zur Literatur (Frankfurt a.M.: Suhrkamp, 1994) 447-91.

${ }^{12}$ Reinhard Zbikowski, "'Schwimmende Hölderlintürme', Paul Celans Gedicht 'Tübingen, Jänner'-diaphan," in "Der glühende Leertext," Annäherung an Paul Celans Dichtung, ed. Christoph Jamme and Otto Pöggeler (München: Wilhelm Fink Verlag, 1993) 185-211.

${ }^{13}$ Recent interpretations include those by Paul Coates, Words After Speech: A Comparative Study of Romanticism and Symbolism (New York: St. Marin's, 1986), Philippe Lacoue-Labarthe, Poetry as Experience, trans. Andrea Tarnowski (Stanford: Stanford UP, 1999), Aris Fioretos, "Nothing, History and Materiality in Celan," Aris Fioretos, Word Traces: Readings of Paul Celan (Baltimore: Johns Hopkins UP, 1994) 295-341, and Fritz Breithaupt, "Echo. Zur neueren Celan-Philologie," Modern Language Notes 110 (1995): 631-57. See also Gérard Raulet, "The Logic of Decomposition; German Poetry of the 1960s,"trans. Sheila Elizabeth Keene and Gail Ellement, New German Critique 21 (1980): 95.
14The "Turm" may refer to the word "himmelstürmende" in Hölderlin's "Das nächste Beste."

${ }^{15}$ Friedrich Hölderlin, Sämtliche Werke und Briefe, vol. II, ed. Jochen Schmidt (Frankfurt: Deutscher Klassiker Verlag, 1994), 329.

${ }^{16}$ See Manfred Geier, Die Schrift und die Tradition. Studien zur Intertextualität (München: Wilhelm Fink Verlag, 1985) 25.

17Walter Benjamin "Über die Sprache überhaupt und über die Sprache des Menschen," Gesammelte Schriften, vol II: 1, 155.

${ }^{18}$ Bernhard Böschenstein, "Tübingen, Jänner'," Über Paul Celan, ed. Dietlind Meinecke (Frankfurt a.M.: Suhrkamp, 1970) 102.

19Jean-François Lyotard, The Postmodern Condition: A Report on Knowledge. Trans. Geoff Bennington and Brian Massumi (Minneapolis: $U$ of Minnesota $P, 1984) 16$.

${ }^{20}$ Georg Büchner. Sämtliche Werke, Briefe und Dokumente, vol I, ed. Henri Poschmann and Rosemarie Poschmann (Frankfurt a. M.: Klassiker Verlag, 1992)164.

21Ilana Schmueli, “'Denk dir': Paul Celan in Jerusalem," Jüdischer Almanach des Leo Baeck Instituts (Frankfurt a. M:: Jüdischer Verlag, 1992) 33.

${ }^{22}$ See Jacques Derrida, "Shibboleth: For Paul Celan," trans. Joshua Wilner, Fioretos, Word Traces 17.

${ }^{23}$ Quoted in Wilhelm Michel, Das Leben Hölderlins (Frankfurt a.M.: Insel, 1967) 435.

${ }^{24}$ See Paul de Man, "The Rhetoric of Temporality," Blindness and Insight; Essays in the Rhetoric of Contemporary Criticism (Minneapolis: U of Minnesota Press, 1983) 187-228.

${ }^{25}$ See Bernhard Böschenstein, "Hölderlin und Celan," Paul Celan, Materialien, ed. Hamacher, Werner and Menninghaus, Winfried (Frankfurt a. M.: Suhrkamp, 1988) 193. Grete Lübbe-Grotthues, "Paul Celans Gedicht 'Ich trink Wein'," Literaturwissenschaftliches Jahrbuch 26 (1985): 359-65; and Klaus Manger, "Die Königszäsur," Hölderlin-Jahrbuch 23 (1983): 156-65.

${ }^{26}$ See Martin Heidegger, "Die Zeit des Weltbildes," (1938) Holzwege (Frankfurt a. M.: Vittorio Klostermann, 1994) 75-113. 